\title{
Diversity and uniformity in genetic responsibility: moral attitudes of patients, relatives and lay people in Germany and Israel
}

\author{
Aviad E. Raz $\cdot$ Silke Schicktanz
}

Published online: 24 July 2009

(c) The Author(s) 2009. This article is published with open access at Springerlink.com

\begin{abstract}
The professional and institutional responsibility for handling genetic knowledge is well discussed; less attention has been paid to how lay people and particularly people who are affected by genetic diseases perceive and frame such responsibilities. In this exploratory study we qualitatively examine the attitudes of lay people, patients and relatives of patients in Germany and Israel towards genetic testing. These attitudes are further examined in the national context of Germany and Israel, which represent opposite regulatory approaches and bioethical debates concerning genetic testing. Three major themes of responsibility emerged from the inter-group and crosscultural comparison: self-responsibility, responsibility for kin, and responsibility of society towards its members. National contrast was apparent in the moral reasoning of lay respondents concerning, for example, the right not to know versus the duty to know (self-responsibility) and the moral conflict concerning informing kin versus the moral duty to inform (responsibility for kin). Attitudes of respondents affected by genetic diseases were, however, rather similar in both countries. We conclude by discussing how moral discourses of responsibility are embedded within cultural (national, religious) as well as phenomenological (being affected) narratives, and the role of public engagement in bioethical discourse.
\end{abstract}

\footnotetext{
A. E. Raz $(\bowtie)$

Department of Sociology and Anthropology, Ben Gurion

University, Beersheba, Israel

e-mail: aviadraz@bgu.ac.il

S. Schicktanz

Department of Medical Ethics and History of Medicine, University Medical Center Göttingen, Göttingen, Germany

e-mail: silke.schicktanz@medizin.uni-goettingen.de
}

Keywords Genetic responsibility - Being affected . Public moralities · Cross-cultural bioethics · Germany . Israel

\section{Introduction}

The importance of adding the perspective of lay moralities to the bioethical discussion of new medical technologies has already been acknowledged, especially in tandem with the increasing role played by the social sciences in the bioethical enterprise (De Vries et al. 2007; De Vries and Kim 2008) and through the creation of "empirical ethics" (Borry et al. 2004, 2005). We compare here for the first time lay attitudes towards genetic testing in Germany and Israel, two countries that offer much for a comparative analysis given their very distinctive approach to regulating genetic testing (Wertz and Fletcher 1989; Hashiloni-Dolev 2007; Gottweis and Prainsack 2006). This study follows the idea that lay people including those affected by genetic diseases provide a richness and complexity of arguments in assessing genetic research and bioethical problems (Scully et al. 2004; Banks et al. 2006). We further ask how the effect of different nation-specific worldviews can be moderated by the lived experience of being affected (Kleinman et al. 1997; Kleinman 1999). This opens up the possibility that values shared across countries could also be culturally informed, for example by values associated with disability that transcend national contrasts.

Recently, lay perspectives on genetic research and genetic testing are gaining more legitimacy and influence through patients' organizations and advocacy groups (Kerr et al. 1998; Petersen 2006; Novas 2006, 2007; Raz 2009). These lay perspectives join the mainstream institutional discussion concerning how to regulate genetic testing so as 
to minimize/avoid stigmatization and discrimination (Chadwick et al. 1999; Chadwick and Thompson 1999; Wolf 1995). We concentrate on genetic testing of adults, which includes carrier and predisposition testing. This is an important area of the new genetics which increases the range of choices open to the healthcare consumer (Slowther 2008; Vallance and Ford 2003). In general, responsibility involves moral and philosophical questions of causality, control and justification (Fischer and Ravizza 1998; Jonas 1979, 1985; Feinberg 1970; Lübbe 1994), which in the context of genetic testing raise questions of respecting self-determination, discreetness, determinism and prevention (Chadwick et al. 1997; Rhodes 1998; Takala and Häyry 2000; Andre et al. 2000). However, most of the work done in this field concentrates on expert responsibility which is discussed from a professional and universalistic point of view. A few studies have shown the existence of contesting lay concepts of "genetic responsibility" in attitudes towards predictive genetic testing of adults (Hallowell 1999; Konrad 2003, 2005; Taylor 2004). Our research further complements these studies by adding a cross-cultural comparison.

After introducing the comparative framework of Israel and Germany and the methodology used in this study, we describe the themes expressed by the respondents and focus on a comparative analysis. Responsibility, a central and multi-faceted theme that emanated from the discussions in both countries, will be presented in a multi-layered fashion-moving from self-responsibility, via responsibility for kin, to the responsibility of society towards its members. We conclude by discussing how moral discourses of responsibility are embedded within cultural (national, religious) as well as phenomenological (being affected) narratives, and the role of public engagement in bioethical discourse.

\section{Comparing Israel and Germany in the context of genetic testing}

In Wertz and Fletcher's (1989) international survey, German geneticists expressed extreme caution regarding the use of prenatal diagnosis (PND) for selective abortion, while Israeli geneticists advocated it. Hashiloni-Dolev (2007) further located these differences within the thriving social, legal and ethical debate concerning reprogenetic technologies in Germany, as opposed to its absence in Israel. While German political, feminist, and disability rights groups actively oppose genetic technology, disability activists in Israel support the use of PND to prevent life with disability ( $\operatorname{Raz} 2004$ ). As Gottweis and Prainsack (2006) show, in Germany the production of human embryonic stem cells is legally forbidden and pre- implantation genetic diagnosis (PGD) is contested because of the moral protection of the human embryo (see also Krones et al. 2005), while in Israel both practices are strongly supported. While genetic testing is practiced in Germany and Israel on a personal choice basis, in Israel there is also a national screening program for genetic diseases such as Tay-Sachs, Cystic Fibrosis, and familial dysautonomia (Zlotogora and Leventhal 2000). In Germany, the issue of genetic screening is discussed separately from and with much more caution than individual genetic testing, partly due to the spectre of Nazi eugenics (Enquete-Kommission 2002; Schroeder-Kurth 1999).

\section{Methodology}

Our point of departure for an integrative analysis of sociology and ethics is that empirical social science could be seen as providing descriptive 'facts' that can be ethically studied as normative statements (Haimes 2002). First, we add to the expert discourse of abstract and formal ethical principles the moral reasoning of lay people, which is ambivalent, informal and "unprincipled"-a morality without foundations which is nevertheless the morality we 'live by.' Second, we add a contextual focus on social categories - in our case lay, affected (here defined as patients or close relative of a patient, see Schicktanz et al. 2008), religious, and national groupings. In addition to providing empirical data for ethical analysis, the sociological analysis of the focus groups and interviews enables new questions to be asked, such as 'why are these issues defined as ethical concerns by these people in these times and these places?' or more concretely: 'why is responsibility as moral duty, rather than a moral conflict, preferred in the context of genetic testing of adults by certain people in Germany and/or in Israel?' Such questions can then be further discussed as indicators of broader concerns and comparative cultural narratives within Germany and Israel. The methodology therefore consists of several iterations between social science and moral philosophy in order to strive for an empirically-informed integration (Birnbacher 1988; van der Scheer and Widdershoven 2004; Borry et al. 2005).

All of the respondents $(N=48)$ in this exploratory and qualitative study were volunteers recruited in Germany (Berlin) and Israel (Beer-Sheva, Jerusalem and Tel-Aviv) during 2005-2007. In Germany, two focus groups were conducted. ${ }^{1}$ In Israel, three focus groups were held with lay

\footnotetext{
1 The German focus groups were recruited, organized and conducted by the Research Group on Bioethics and Science Communication at the Max-Delbrück-Center for Molecular Medicine Berlin-Buch in the beginning of 2005 in the framework of the EU-Project "Challenges of Biomedicine", Contract No. SAS6-CT-2003-510238.
} 
people and 10 people affected by genetic diseases were interviewed individually, as per their preference. All 32 Israeli respondents were Jewish by birth but only seven defined themselves as religious. Seven of the 16 German respondents defined themselves as Protestants, seven as atheists, and the remaining two were a Buddhist and a Muslim. Similar scenarios and questions were used in the focus groups and individual interviews (Carter and Henderson 2005; Bloor et al. 2001). Focus groups in Israel and Germany included 7-8 people and lasted about $2 \mathrm{~h}$; individual interviews lasted about $1 \mathrm{~h}$ on average. The age range across all respondents was 18-65 with an average of 34. In terms of formal education, all participants had a high-school diploma; 58 and $42 \%$ of the German and Israeli respondents, respectively, had a BA-level university degree. The groups' composition was heterogeneous with respect to socio-demographic criteria like age, educational level and religion. There were slightly more women than men in each group. On the basis of their self-assessment in the pre-questionnaire, the selected participants were ascribed the status 'lay' or 'affected' according to their personal experience.

German respondents affected by genetic diseases were recruited from self-help and support organizations and included people who tested positive, or had children who tested positive, for a variety of genetic diseases/conditions including Marfan syndrome, muscular dystrophy, dwarfism, and cystic fibrosis. Israeli respondents affected by genetic diseases were recruited from organizations of and for people with genetic diseases and included people who tested positive, or had children who tested positive, for a variety of genetic diseases/conditions including cystic fibrosis, Prader-Willi Syndrome, Rett Syndrome, and thalassemia. The category of "being affected" is thus comprised in this study of people who either have genetic diseases or have children with genetic diseases. After finding that similar views were expressed by these two subgroups, we decided to amalgamate them for the purpose of this study into one group. Of note, while differences in attitudes between people who have genetic diseases and people who have children with genetic diseases have been found in the context of prenatal testing, our focus in this study is on carrier testing of adults, and many of the parents of children with genetic diseases have themselves gone through genetic counselling following the birth of the affected child. German and Israeli respondents not affected by genetic diseases were recruited by disseminating flyers and ads in urban public places.

Questions asked in the focus groups and interviews included attitudes towards genetic testing of adults, such as: Who influences the decision to test (family members, partners, health professionals, the state and so on), when and how; who is seen as responsible for making the decision and why; who is seen as having the authority to decide and what are the sources of such authority (religion, morality, the law and so on). Respondents were not provided with any preliminary instruction since we were interested in their ordinary attitudes. Scenarios regarding carrier testing of adults (for example in the context of breast cancer) were used in Germany and Israel to provide a concrete narrative that invites participants to imagine a real case, to consider what other information they would need to know to make a judgment, to consider the reasons and motives of significant others, and so on. Group discussions and interviews were audio recorded and transcribed. The authors analyzed the transcripts from each country thematically, then translated them from Hebrew and German into English and compared the themes crossnationally in order to uncover discursive categories recurring within and across groups (Denzin and Lincoln 1994). The quotations given illustrate the range of responses with regard to the emerging themes. After analyzing the 'national' themes in detail for their contents and arguments, we focused on the comparison of similar crosscultural themes.

\section{Empirical analysis: genetic testing as a locus of responsibility}

The issue of responsibility emerged as a central and multifaceted theme in the moral deliberations of German and Israeli respondents. Genetic testing was discussed by a few of the German and Israeli respondents as negating responsibility, i.e., regarding genetic causes as relieving one's personal responsibility for the disease, since if a disease is inherited, the parents are held responsible. However, this minority view was criticised by most of the respondents, who argued that the fact that these risks are involuntary does not absolve gene carriers of responsibility for their health. Indeed, as Hallowell (1999, p. 599) found, "because genetic risks are portrayed as part of the individual's make up their responsibility to act to protect their health, or the health of future generations, is emphasized, for inherited risk cannot be blamed upon external sources."

The majority view thus regarded genetic testing as a source of responsibility concerning one's lifestyle and relatives as well as the responsibility of society towards pre-symptomatic 'patients.'

For the majority of German and Israeli respondents, genetic testing of adults without the option of a therapy was regarded very skeptically. Since merely the knowledge alone could induce psychological stress as well as social surveillance and discrimination, it could cause a disease escalation. Pre-symptomatic or carrier testing that only 
produced statements of risk probabilities were therefore regarded by the majority of German respondents as inadvisable:

But I believe that if you get signs in that manner, [...] this will also lead to a state of panic or perhaps even to paranoia. And I believe that this is not necessarily positive for ... your quality of life. (Female, German, not affected by genetic disease)

This criticism was more elaborated on amongst German respondents. For example, it was linked by some German respondents to the broader context of the social construction of illness. It was argued that since some genetic conditions (e.g., dwarfism) are socially constructed as a handicap, testing for them, generally speaking, is yet another mechanism of this social construction:

Well, my maternal grandparents were relatively small people but they did not suffer from dwarfism [...] But now doctors are quite sure that my son is suffering from delayed growth. (Female, German, family affected by dwarfism)

In addition, a small group of German respondents, who were mainly non-affected and presented themselves as Protestant, stressed their will to "take things as they come" (female, affected as mother from a son with hereditary dwarfism). If no concrete actions or consequences were deducible from the test, according to these respondents, they would object to "knowing what destiny holds". This right not to know could be seen as objection of selfresponsibility as there is no causality nor this knowledge will have no consequences. Individuals who presented for Huntington's Disease (HD) predictive testing similarly defended the right, in principle, of at-risk individuals "not to know" their HD gene status (Taylor 2004). This 'right not to know' was mentioned by our respondents as an individual, personal right but not as a general argument against passing genetic information.

I myself wouldn't like to know. And I think, what is the good of having this forecast? And the first question would be whether this is bound to come true. (Male, German, not affected by genetic disease)

However, as long as the genetic test could have medically therapeutic or preventive consequences, most of the German and Israeli participants were in favor of it. This agreement was the basis for a perceived self-responsibility associated with genetic testing. Most of the respondents agreed that even though genetic testing will not prevent the disease, at an early stage of detection it could prolong life and increase one's opportunities:
In my case this Marfan Syndrome [...] Well, it has affected my vascular system. That's why I had to have a heart transplantation 8 years ago. I mean, if you know right from the start that you have a certain disease, you'll cope with it differently. For example not participating in sports in order not to overstrain yourself. (Female, German, affected by genetic disease)

I'm also of the opinion that if I had known this earlier I would not have done certain things. [...] the medication could really have started earlier. (Female, German, affected by an undiagnosed hereditary disease)

Many participants-especially women but also men, in Germany and Israel-mentioned breast cancer as a disease which is potentially curable if detected early. They stated they would like to take a genetic test, especially if there was further information such as for example the occurrence of breast cancer in their family:

If for example you come from a family with a history of breast cancer and if it was possible to say with the help of a genetic test whether it could be passed to your own children, you would keep an eye on everything right from the outset. Because breast cancer is for example curable, if detected early. (Female, German, affected by genetic disease)

If you tested positive for it, then you become more watchful for additional medical examinations. Instead of having mammograms once a while, you have one every six months. (Female, Israeli, not affected by genetic disease)

I have relatives who have to go for testing since their parents had died from the same thing. It can be prevented if you have the testing done and remove the polyp. (Male, Israeli, affected by genetic disease)

While the potential stress that might follow a positive test was also mentioned by some of the respondents, it was weighted against the potential benefits of the test:

The stress can be like a black cloud hanging over your head while chances are you are not necessarily going to get cancer. But then again it might also help you. (Female, Israeli, not affected by genetic disease)

The majority of the respondents describe a concept of selfresponsibility which parallels the 'self-government' (Lemke 2002, 2005; Novas and Rose 2000) of one's own behaviour and body. It includes the consquentialistic idea of controlling one's life style and health behaviour (i.e., periodic 
medical tests) in light of future outcomes. Some Israeli respondents also supported genetic testing on the basis of belonging to a high-risk group:

There are no genetic problems in my family at present, but I am not so sure about previous generations since many have gone in the Holocaust. You know, Ashkenazi Jews have more mutations than others, so you cannot be too careful. It is better to do the test, just to be on the safe side, and then see what are the implications. (Female, Israeli, not affected by genetic disease)

This shared view of genetic risk, which means that belonging to a certain group such as Ashkenazi Jews results in a higher genetic risk for the group member than other persons, was also expressed by a few Israeli respondents in the form of what they regarded as a 'duty to know':

Even if in my own family there are no cases of cancer, just being an Ashkenazi woman means that I am under greater risk and should consider testing. It also makes sense to pay for the predictive test, since, if you are a carrier, it means that you have to do the screening more frequently, and maybe the State will subsidize it in case you are a carrier. (Female, Israeli, not affected by genetic disease)

Some Israeli respondents also referred to the duty to know as part of one's required health maintenance which even has religious orientation:

There is the Jewish principle of the overriding value of curing, and it is our religious duty to make an effort (hishtadlut). Efforts to intervene in nature, for example through predictive testing, is in principle taking the powers with which God endowed us and putting them to good use. (Male, Israeli, affected by genetic disease)

Here, the idea of self-responsibility to undergo a genetic test seems to be justified not only because of future consequences but as part of a particular Jewish identity. Some of the German respondents who were affected by genetic diseases also spoke-in a parallel manner to lay and affected Israeli respondents-about the duty to know and to tell close family members:

I'd consider it to be my duty. Yes. Well, I've always kept my relatives informed of how my disease made its way through the genes of my family [...] When everything, I mean, all the trouble has started, well, I told her [my sister] that it's a thing which can be transmitted by men. But if these women have babies themselves, this may/their children may be, well, disabled. (Male, German, affected by hereditary disease)

This issue of knowing the genetic information and passing it to kin, regarded as a duty by many Israeli respondentsboth affected and not affected-as well as by affected German respondents, brings us to the theme of responsibility to one's kin.

\section{Responsibility for kin}

Kenen (1994) and Hallowell (1999) argue that the increasing availability of genetic information results in individuals acquiring an obligation to reveal genetic information about themselves to their kin. In contrast, Konrad (2003, 2005) describes the negotiation of (non)disclosure as a moral conflict. Taylor (2004) describes the decision to test as morally contingent on the perceived need of oneself and significant others for the genetic test information and the capacity to tolerate, manage and live with such information. While the former view was described by respondents in the context of breast cancer and potential preventive treatment, the latter is linked to Huntington's Disease and no pre-emptive treatment. These two opposite narratives of responsibility for kin-moral duty versus moral conflict - were also present amongst our respondents. These two kinds of responsibility could be seen as two sides of the same coin, as in both cases it is about the moral care for people you loves and feel bonded to.

While non-affected German respondents saw a moral conflict in passing the information, affected respondents stressed that there is a moral duty to do so. Of note, we did not find any clear gendered patterns within or across the groups. The non-affected view preferred the protection of the kin's right not to know-thus protecting them from too much information that could cause futile anxiety:

I have a younger sister. [...] she is very emotional. And this means, that she nurses bad news for a very long time. And no matter if there is a real reason for it or not. [...]. And this means, that if I told her, I knew that she probably would nurse it for the rest of her life. That she, no matter if she really fell ill or not, during the rest of her life she would have a fear that she might fall ill. And this could have a permanent influence on her life. (German, male, not affected)

The moral conflict was described as consisting of, on the one hand, the moral responsibility towards kin, but on the other hand the recognition that how to handle such information is a genuinely individual decision - especially information about health and the body, which everybody 
has to care for on their own. The conflict is, as one respondent said, caused by the knowledge itself:

I don't want to say that I would consider it my duty to, but for reasons of morality, I do think that I would tell. Just because of, should something really happen, that nobody makes an issue out of it later by saying: Heavens! You really knew something. You underwent the test. Why didn't you inform us? ... It certainly is very difficult. [...] Well, maybe they say: and now you got us all into a real mess, [...] This certainly is the big problem with genetic tests. (German, Male, not affected)

But it is really astonishing, what a responsibility such knowledge may cause. [...] you should be aware of it right from the start. Then there is the question, well, what does the responsibility include? I mean to say, am I only responsible for myself alone? I do not need to tell it to somebody else, because it is my case, my life, my disease or my susceptibility. Or you are so, do I quite have the responsibility to say: Well, when I have this susceptibility to it, you as my sister has it as well and that is why I am responsible for your life, too. (German, female, not affected)

The majority of German affected respondents agreed on the moral duty to inform family members, especially if it could have relevance for planning life and reproduction, particularly in terms of potential children's health. Such responsibility can thus be regarded as entailing both selfgovernment and the government of others.

I also have a brother and he told me that he also wanted to have children. Well, after I had read up on it, I told him that he might transmit the Marfan Syndrome. He had an examination. But as I said before, time went by and they [the doctors] haven't received the results of the tests yet. So he has two children now [...]. And they are as fit as a fiddle. Even though one of his children is a bit like my daughter, well, a little bit -always a bit cool, always a bit different. Well. I observe that from a distance and tell him every now and then to [...] keep an eye on it. That's all I can do. (German, female, affected)

The majority of Israeli respondents, both affected and not affected, also agreed about the moral duty to pass the information to one's kin:

My father told me that he was diagnosed with a heart condition that has a genetic basis. I think it was his duty to tell me that so that I can be aware and take measures regarding myself and my children. For example, my son will be in the military next year, and this information means that he should take the test too
- if he has the condition or a potential to develop it, this might have consequences for his military service. (Israeli, female, affected)

Of course, I would like my kin to tell me about positive or negative genetic test results, and I would do the same for them. It is part of being a family and caring for each other. Even if there are no medications or pre-emptive treatment for the genetic condition, I would still want to be told - it is possible that in the future some treatment would be available. (Israeli, female, not affected)

\section{Responsibility of society towards its members}

In this section we refer to several themes that relate to the perception of the responsibility of society concerning economic and discriminatory aspects of genetic testing of adults. Of note, none of the respondents mentioned a personal responsibility for society. In that sense there was no argument related to eugenics or population genetics. Most German respondents voiced concern that because of its costs, only the rich would have access to genetic tests of adults:

No health scheme will pay for it [...] Anyone who has to live on social security would not have the money to undergo a genetic test. This is a social question of responsibility. (Male, German, not affected by genetic disease)

Most Israeli respondents did not share the German respondents' critical outlook concerning the linkage between genetic testing of adults and health disparities. On the contrary, the majority expressed the view that such testing has already become "a public matter," made available to everyone through State-supported and subsidized screening programs:

It's like the national carrier screening program for Tay Sachs that we have. It's for everyone, and people take it without having to pay. I expect that such services will be increasingly offered to the public in the context of genetic diseases that are prevalent in the Jewish population. (Male, Israeli, not affected by genetic disease)

We are all in the same boat in this matter so I expect testing will be subsidized by HMOs [Health Management Organizations]. It is a simple cost-benefit calculation for the State or the health organization. It should be cheaper to test and prevent suffering than not to test and then treat. (Female, Israeli, affected by genetic disease) 
Worries concerning discrimination due to genetic information were voiced by most of the respondents, German and Israeli, and there was a consensus that genetic information should always be kept confidential unless otherwise decided by the patient. Especially with respect to insurance companies, a fear was expressed that genetic data on predispositions could amplify the current erosion of solidarity in the field of insurance coverage. Another view on discrimination was expressed by some affected German respondents and Israeli respondents (both affected and not affected), who related to such genetic information as a potential source of affirmative action or 'positive discrimination':

If I knew in advance that I had this inherited defect, I would go to the doctor every three months and have a mammogram made. The health insurance would pay for it then. (German, female, affected)

Doctors always tell us how preventive medicine saves millions of dollars. I guess if I found out I was presymptomatic for breast cancer that would mean being entitled to discounted preventive treatments. It's the same as the state paying for amniocentesis of pregnant women who already have children with inherited diseases. (Israeli, male, not affected)

\section{Comparing the themes between the groups and cross-culturally}

Three major themes concerning responsibility emerged from the empirical analysis: self-responsibility, responsibility for kin, and the responsibility of society. A comparison of these themes between Germany and Israel (summarized in Table 1) supports the following generalizations:

A practical consensus emerged in regard to a positive view of genetic testing, as long as it could lead to an improvement in life through changes in lifestyle or preventive treatment. This practical line of reasoning was also found in other studies among various populations showing that in making such a decision people take into account factors such as the predictive value of the test and control over the disease. Together, these studies show that when the predictive value of the test and the control over the disease (availability of cure/treatment) were perceived as high, more interest in testing was expressed (Shaw and Bassi 2001; Shiloh et al. 1999; Barnoy 2007). In addition, worries about negative discrimination were also prevalent among the German and Israeli groups.

German non-affected respondents expressed greater scepticism than did Israeli respondents. For example, German non-affected respondents agreed that responsibility for

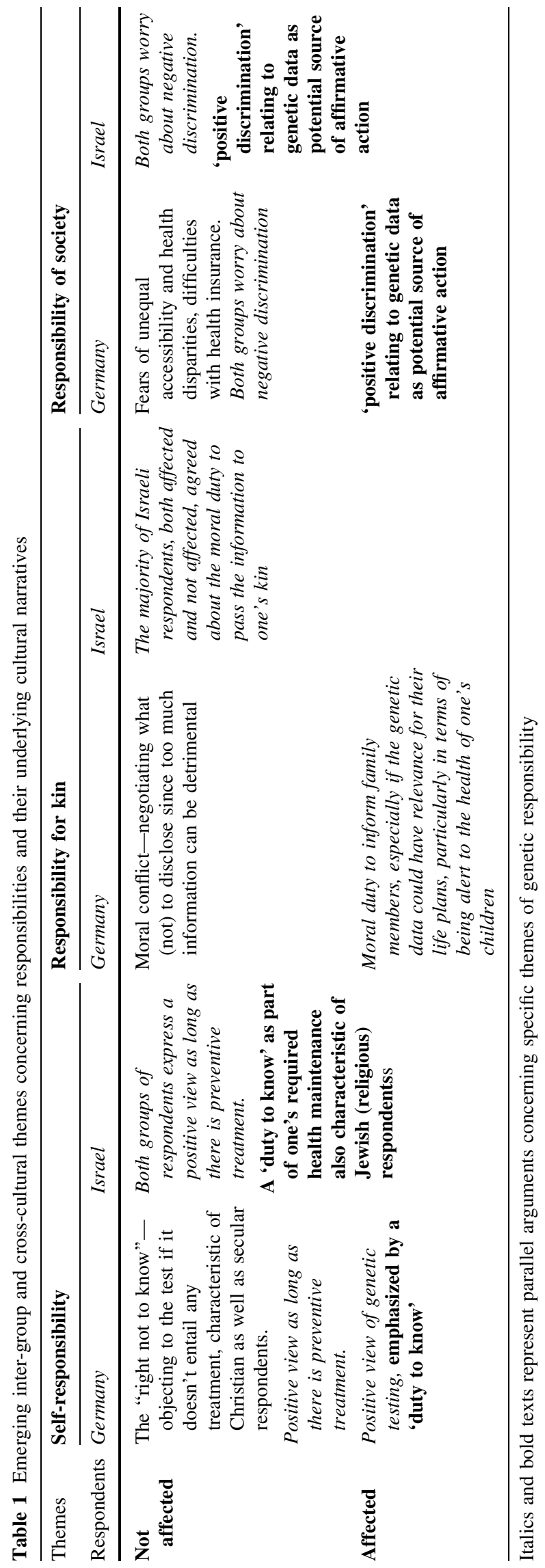


kin generates moral conflict rather than moral duty; some of them also believed there is a "right not to know" and expressed worries about the emergence of a two-tiered health market. In contrast, German affected respondents were more categorical, sharing with Israeli affected respondents a view of self-responsibility as a duty to know, of responsibility for kin as moral duty, and of social responsibility as requiring 'positive discrimination.'

In Israel, unlike Germany, the views of respondents who were not affected by genetic diseases were overall similar to those of Israeli respondents affected by genetic diseases. The "duty to know and tell" stresses this linkage by reflecting as well as constructing a shared sense of genetic risk.

In the ensuing conclusion we offer some preliminary interpretations of these patterns and their implications.

\section{Concluding remarks}

Our findings complement and extend the accepted view of Germany and Israel as opposing examples of bioethical culture in relation to genetic testing. This study demonstrates that professional opinions provide only one layer for the comparison of cultures, a comparison which should also include lay/affected people. While involving parallel contentions to those raised by our respondents, the professional ethical debate on what shapes responsibility in the context of genetic testing of adults usually centered on the notion of individual responsibility. The liberal intuition that individuals have at least a right to ignore the genetic information concerning themselves (Chadwick 2004) can be challenged by the position that to make autonomous choices, individuals should first acquire all the relevant genetic information concerning the situation they find themselves in (Rhodes 1998), as well as by a consequentialist position which criticises ignoring such information as potentially inflicting avoidable harm on the health of one's children (Takala and Häyry 2000).

The analysis of focus groups demonstrated the complexity of the concept of responsibility and how it is embedded in the social world of particular groups. Our study highlighted various cultural and personal narratives that underlie the multi-faceted notion of responsibility, narratives which had a pivotal role in the moral deliberations. In the context of self-responsibility, the moral conflict and the right not to know in case no therapy exists-a view expressed mainly by German lay respondents-could be linked to what Lemke (2005) referred to as 'genetic fatalism'. This may represent the Christian 'stewardship' model associated with criticism of genetic interventions as "playing God" (Walter 1999). Alternatively, for most people without a clear medical family history, ignoring genetic information about hereditary properties can be ethically advisable if they are willing to unconditionally nurture a child whatever her genetic characteristics may be (Vehmas 2001). The duty to know, as expressed by Israeli lay/affected respondents, could be linked to the Jewish support of medical efforts to intervene in nature (Gross and Ravitsky 2003, p. 251).

In the context of family responsibility, the pivotal issue was the ambivalence whether to tell or not to tell. Israeli respondents developed a moral argument regarding the duty to know and the obligation to tell as part of being a member of a close-knit family - expecting to be told by others in the family and feeling an obligation to tell them. In a parallel manner, Hallowell (1999) described genetic responsibility in the context of women seeking predictive genetic counselling for breast cancer even while compromising their own needs of 'not knowing' their risks for the sake of relaying the genetic information to their kin. In contrast, the German ambivalence could be linked to a perception of relatively loose-knit, ethnically heterogeneous families, where the concept of care for your kin includes a respect for being different, genetically as well as personally. As genetic tests become knowledge that should or should not be shared, it creates new options of acting but also of power. Konrad (2003, 2005) and Taylor (2004) also showed how pre-symptomatic genetic counselling for Huntington's Disease (HD) can turn into moral negotiation within and between family members, involving complex decision-making over the (non-)disclosure of genetic information about their own and others' health futures.

In the context of the responsibility of society, the shared perception of 'positive discrimination' by Israeli respondents could be linked to their communitarian sense of belonging to an "at-risk population." Strong reliance on a collective body is here linked to moral expectations from society and a sense of responsibility to the collective (Weiss 2002), also consistent with the strong sense of a duty to tell other family members about their risk status. In contrast, the skeptical outlook of some German respondents concerning health disparities could be interpreted as related to the perceived breakdown of social solidarity. At this moment in the German history of health care, many Germans criticize the ongoing development of a two-tiered system of health care that allows the rich to receive better medicine and better care by holding private health insurance policies (for additional survey data see Schoen et al. 2009).

Finally, this study illustrates how responsibility, as a key term in the moral deliberation, is embedded both in national culture and lived experience. Some of the deliberations may be related to different individual understandings of responsibility, predictability and trust concerning genetic testing of adults. However, in all three categories of responsibility, the views of German affected respondents 
were different from those of non-affected German respondents but quite similar to those of Israeli affected respondents. The lived experience of being affected, which also includes perceived genetic risk, thus arguably produces a common moral worldview that can transcend national contrasts. Perhaps what this tells us is that the experience of vulnerability enhances one's perception of relationality, i.e. of being part of a group. Being affected probably makes a cognitive difference, constituting an epistemic authority and a strong motivation for information acquisition (Schicktanz et al. 2008). In a similar manner to the knowledge claims of feminist standpoint or situated knowledge theorists, critical race theorists and disability studies perspectives (Harding 2004; Johnstone 2001), affected people may warrant an "expert status" for their own situation and concerns (Badcott 2005). This also has implications for ethical norms grounded not just in the professionals' viewpoints but also in the perspectives of patients.

In Israel, where the "Ashkenazi Jewish gene pool" has been constructed by health professionals as especially prone to inherited disorders, 'genetic anxiety' (or 'responsibility,' depending on one's perspective) has been boosted, creating a collective sense of risk in which the 'elective' uptake of genetic testing is exceptionally high and seen by many as moral duty (Remennick 2006; Sher et al. 2003). The duty to tell, as shared by Israeli respondents, matches Israel's Genetic Information Law (2000) which, quite uniquely compared to international regulation, prescribes that genetic information could be communicated to third parties if it is "required for the maintenance of the health of a relative or to improve such person's health, and for the prevention of death, illness or serious disability of such relative, including an unborn relative." Such dutybased legal responsibility could also lend itself to Foucauldian interpretation as a biopolitical fabrication of the self and a symptom of bio-governmentality turning individuals into self-inspectors of themselves and their DNA (Novas and Rose 2000). In our study, the view regarding the "duty to know" encapsulated and emphasized the general Israeli consensus regarding the benefit of genetic testing. A collective lay notion of "being affected," which requires further sociological analysis, could thus explain why the Israeli lay morality of responsibility is in fact a morality of being affected. This study implies that a multifaceted awareness of the variety of public views, including the attitudes of those affected and not affected, warrants attention for improving lay-professional communication, tackling ethical questions, and formulating future policy.

Acknowledgements We would like to thank Mark Schweda, who contributed to the data coding and preliminary interpretation of the German focus group discussions, as well as the anonymous reviewers.
Open Access This article is distributed under the terms of the Creative Commons Attribution Noncommercial License which permits any noncommercial use, distribution, and reproduction in any medium, provided the original author(s) and source are credited.

\section{References}

Andre, J., L. Fleck, and T. Tomlinson. 2000. On being genetically "irresponsible". Kennedy Institute of Ethics Journal 10: 129-146.

Badcott, D. 2005. The expert patient: Valid recognition or false hope? Medicine, Health Care and Philosophy 8: 173-178.

Banks, S., J.L. Scully, and T. Shakespeare. 2006. Ordinary ethics: The ethical evaluation of the new genetics by lay people. New Genetics and Society 25 (3): 289-303.

Barnoy, S. 2007. Genetic testing for late-onset diseases: Effect of disease controllability, test predictivity, and gender on the decision to take the test. Genetic Testing 11 (2): 187-193.

Birnbacher, D. 1988. Verantwortung für zukünftige Generationen. Stuttgart: Reclam.

Bloor, M., J. Frankland, M. Thomas, and K. Robson. 2001. Focus groups in social research. London: Sage.

Borry, P., P. Schotsmans, and K. Dierickx. 2004. What is the role of empirical research in bioethical reflection and decision-making? An ethical analysis. Medicine, Health Care and Philosophy 7 (1): 41-53.

Borry, P., P. Schotsmans, and K. Dierickx. 2005. The birth of the empirical turn in bioethics. Bioethics 19 (1): 49-71.

Carter, S., and L. Henderson. 2005. Approaches to qualitative data collection in the social sciences. In Handbook of health research methods: Investigation, measurement and analysis, ed. A. Bowling and S. Ebrahim, 215-229. Maidenhead: Open University Press.

Chadwick, R., ed. 1999. The ethics of genetic screening. Dordrecht: Kluwer.

Chadwick, R. 2004. The right not to know: A challenge for accurate self-assessment. Philosophy, Psychiatry, \& Psychology 11 (4): 299-301.

Chadwick, R., and A.K. Thompson, eds. 1999. Genetic information: Acquisition, access, and control. Dordrecht: Kluwer.

Chadwick, R., M. Levitt, and D. Schickle, eds. 1997. The right to know and the right not to know. London: Ashgate.

De Vries, R., and S. Kim. 2008. Bioethics and the sociology of trust: Introduction to the theme. Medicine, Health Care, and Philosophy 11: 377-379.

De Vries, R., L. Turner, K. Orfali, and C. Bosk, eds. 2007. The view from here: Bioethics and the social sciences. Oxford: Blackwell.

Denzin, N.K., and Y. Lincoln. 1994. Handbook of qualitative research. Thousand Oaks: Sage.

Enquete-Kommission. 2002. Recht und Ethik der modernen Medizin: Abschlussbericht. Bundestag Drucksache 14/9020 Parliamentary Advisory Council on Law and Ethics of Modern Medicine. Berlin: The German Parliament.

Feinberg, J. 1970. Doing and deserving: Essays in the theory of responsibility. Princeton, NJ: Princeton University Press.

Fischer, J.M., and M. Ravizza. 1998. Responsibility and control: A theory of moral responsibility. Cambridge: Cambridge University Press.

Gottweis, H., and B. Prainsack. 2006. Emotion in political discourse: Contrasting approaches to stem cell governance: The US, UK, Israel, and Germany. Regenerative Medicine 1: 823-829.

Gross, M.L., and V. Ravitsky. 2003. Israel: Bioethics in a Jewishdemocratic state. Cambridge Quarterly of Healthcare Ethics 12: $3247-3255$. 
Haimes, E. 2002. What can the social sciences contribute to the study of ethics? Theoretical, empirical and substantive considerations. Bioethics 16 (2): 89-95.

Hallowell, N. 1999. Doing the right thing: Genetic risk and responsibility. Sociology of Health and Illness 21 (5): 597-621.

Harding, S., ed. 2004. The feminist standpoint theory reader: Intellectual and political controversies. New York: Routledge.

Hashiloni-Dolev, Y. 2007. A life (un)worthy of living: Reproductive genetics in Israel and Germany. Berlin: Springer-Kluwer.

Johnstone, D. 2001. An introduction to disability studies. London: David Fulton Publishers.

Jonas, H. 1979. Das Prinzip Verantwortung: Versuch einer Ethik für eine technologische Zivilisation. Frankfurt/M.

Jonas, H. 1985. Technik, Medizin und Ethik: zur Praxis des Prinzips Verantwortung. Frankfurt am Main: Insel-Verlag.

Kenen, R. 1994. The Human Genome Project: Creator of the potentially sick, potentially vulnerable and potentially stigmatized? In Life and death under high technology medicine, ed. I. Robinson. Manchester: Manchester University Press.

Kerr, A., S. Cunningham Burley, and A. Amos. 1998. The new genetics and health: Mobilising lay expertise. Public Understanding of Science 7: 41-60.

Kleinman, A. 1999. Moral experience and ethical reflection: Can ethnography reconcile them? A quandary for 'The New Bioethics'. Daedalus 128 (4): 69-97.

Kleinman, A., V. Das, and M. Lock. 1997. Social suffering. Berkeley: University of California Press.

Konrad, M. 2003. Predictive genetic testing and the making of the pre-symptomatic person: Prognostic moralities amongst Huntington's-affected families. Anthropology \& Medicine 10 (1): 23-49.

Konrad, M. 2005. Narrating the new predictive genetics: Ethics, ethnography and science. Cambridge: Cambridge University Press.

Krones, T., E. Schlüter, and K. Manolopoulos. 2005. Public, expert and patients opinions on preimplantation genetic diagnosis in Germany. Reproductive Biomedicine Online 10 (1): 116-123.

Lemke, T. 2002. Genetic testing, eugenics, and risk. Critical Public Health 12 (3): 283-290.

Lemke, T. 2005. Beyond genetic discrimination: Problems and perspectives of a contested Notion. Genomics, Society and Policy 1 (3): 22-40.

Lübbe, W. 1994. Kausalität und Zurechnung: über Verantwortung in komplexen kulturellen Prozessen. Berlin: de Gruyter.

Novas, C. 2006. The political economy of hope: Patients' organizations, science and biovalue. BioSocieties 1: 289-305.

Novas, C. 2007. Genetic advocacy groups, science and biovalue: Creating political economies of hope. In New genetics, new identities: Genetics and society, ed. P. Atkinson, P. Glasner, and H. Greenslade, 11-27. London, UK: Routledge.

Novas, C., and N. Rose. 2000. Genetic risk and the birth of the somatic individual. Economy and Society 29 (4): 485-513.

Petersen, A. 2006. The best experts: The narratives of those who have a genetic condition. Social Sciences and Medicine 63: 32-42.

Raz, A. 2004. 'Important to test, important to support': Attitudes toward disability rights and prenatal diagnosis among leaders of support groups for genetic disorders in Israel. Social Science and Medicine 59 (9): 1857-1866.

Raz, A. 2009. Community genetics and genetic alliances: Eugenics, carrier testing, and networks of risk. NY and London: Routledge (Forthcoming).
Remennick, L. 2006. The quest after the perfect baby: Why do Israeli women seek prenatal genetic testing? Sociology of Health and Illness 28 (1): 21-53.

Rhodes, R. 1998. Genetic links, family ties, and social bonds: Rights and responsibilities in the face of genetic knowledge. Journal of Medicine and Philosophy 23: 10-30.

Schicktanz, S., M. Schweda, and M. Franzen. 2008. 'In a completely different light'? The role of being affected for epistemic perspectives and moral attitudes of patients, relatives and lay people. Medicine, Health Care and Philosophy 11: 57-72.

Schoen, C., R. Osborn, S. How, M. Doty, and J. Peugh. 2009. In chronic condition: Experiences of patients with complex health care needs in eight countries. Health Affairs 28: 1-16.

Schroeder-Kurth, T. 1999. Screening in Germany. In The ethics of genetic screening, ed. R. Chadwick, et al., 81-89. Dodrecht: Kluwer.

Scully, Jackie Leach, Rippberger, Christine, and Christoph, Rehmann-Sutter. 2004. 'Nonprofessionals' evaluations of gene therapyethics'. Social Science \& Medicine 58(7): 1415-1425.

Shaw, J.S., and K.L. Bassi. 2001. Lay attitudes toward genetic testing susceptibility to inherited diseases. Journal of Health Psychology 6: 405-423.

Sher, C., O. Romano-Zelekha, M.S. Green, and T. Shohat. 2003. Factors affecting performance of prenatal genetic testing by Israeli Jewish women. American Journal of Medical Genetics 120A (3): 418-422.

Shiloh, S., R. Ben-Sinai, and G. Keinan. 1999. Effects of disease controllability, predictivity and information seeking styles on interest in predictive genetic testing. Person Social Psychol Bulletin 25: 1187-1195.

Slowther, A. 2008. Predictive testing and population screening. Clinical Ethics 3 (1): 11-13.

Takala, T., and M. Häyry. 2000. Genetic ignorance, moral obligations and social duties. Journal of Medicine and Philosophy 25: 107113.

Taylor, S. 2004. Predictive genetic test decisions for Huntington's disease: Context, appraisal and new moral imperatives. Social Science and Medicine 58 (1): 137-149.

Vallance, H., and J. Ford. 2003. Carrier testing for autosomalrecessive disorders. Critical Reviews in Clinical Laboratory Sciences 40 (4): 473-497.

van der Scheer, L., and G. Widdershoven. 2004. Integrated empirical ethics: Loss of normativity? Medicine, Health Care and Philosophy 7: 29-71.

Vehmas, S. 2001. Just ignore it? Parents and genetic information. Theoretical Medicine 22: 473-484.

Walter, J. 1999. Theological issues in genetics. Theological Studies 60 (1): 124-134.

Weiss, M. 2002. The chosen body: Politics of the body in Israeli society. Stanford: Stanford University Press.

Wertz, D.C., and J. Fletcher, eds. 1989. Ethics and human genetics: A cross cultural perspective. Berlin: Springer-Verlag.

Wolf, S.M. 1995. Beyond genetic discrimination: Toward the broader harm of geneticism. Journal of Law, Medicine \& Ethics 23: 345353.

Zlotogora, J., and A. Leventhal. 2000. Screening for genetic disorders among Jews: How should the Tay-Sachs screening program be continued? Israel Medical Association Journal 2: 665-667. 